Himmatul Ulyah: Kebijakan Pendanaan dan Deviden

\title{
KEBIJAKAN PENDANAAN DAN DIVIDEN DENGAN PENDEKATAN ISVEST- MENT OPPORTUNITY SET
}

\author{
Himmatul Ulyah \\ Universitas Airlangga \\ Email : ulyah.aja@gmail.com
}

\begin{abstract}
This study aims to see differences in funding policies and dividend policies between high-potential and high-growth manufacturing firms with Investment Opportunity Sets. The results show that there is a significant difference in funding policy between high-growth and potential firms with low-growth firms using investment opportunity sets. The resulting significant value is 0.014 where the value is lower than 0.05 . There is a significant difference in the dividend policy between a highgrowth and high-potential manufacturing company with an investment opportunity set. The resulting significant value is 0.006 where the value is lower than 0.05 .
\end{abstract}

Keyword: Investment Opportunity Sets, Funding Policies, Divident Policies

\begin{abstract}
ABSTRAK
Penelitian ini bertujuan untuk melihat perbedaan kebijakan pendanaan dan kebijakan dividen antara perusahaan Manufaktur yang berpotensi tumbuh tinggi dan perusahaan yang berpotensi tumbuh rendah dengan menggunakan investment opportunity set. Hasil penelitian menunjukkan terdapat perbedaan yang signifikan pada kebijakan pendanaan antara perusahaan manufaktur yang berpotensi tumbuh tinggi dan perusahaan yang berpotensi tumbuh rendah dengan menggunakan investment opportunity set. Nilai signifikan yang dihasilkan adalah sebesar 0,014 dimana nilai tersebut lebih rendah dari 0,05. Terdapat perbedaan yang signifikan pada kebijakan deviden antara perusahaan manufaktur yang berpotensi tumbuh tinggi dan perusahaan yang berpotensi tumbuh rendah dengan menggunakan investment opportunity set. Nilai signifikan yang dihasilkan adalah sebesar 0,006 dimana nilai tersebut lebih rendah dari 0,05.
\end{abstract}

Kata Kunci : Investment Opportunity Sets, Kebijakan Pendanaan, Kebijakan Dividen 
Ihtiyath Vol. 2 No. 1 September 2018

\section{PENDAHULUAN}

Pertumbuhan perusahaan secara sederhana adalah tingkat keuntungan perusahaan atau seberapa besar perusahaan dapat memberikan imbal hasil kepada para investornya dan adanya kemampuan membayar kewajiban kepada para kreditor. Pertumbuhan perusahaan merupakan suatu hal yang menjadi harapan, baik oleh pihak internal perusahaan yaitu pihak manajemen maupun eksternal perusahaan seperti investor dan kreditor (Julianto Agung Saputro. 2003:69-92).

Nilai perusahaan merupakan gabungan antara aktiva riil dengan pilihan investasi di masa yang akan datang. Oleh karena itu, perusahaan yang memiliki potensi tumbuh tinggi di identifikasi sebagai perusahaan yang mengalami peningkatan pada aktiva riilnya dan peningkatan pada peluang investasi yang ada. Perusahaan yang memiliki potensi tumbuh rendah diidentifikasi sebagai perusahaan yang kurang mengalami peningkatan pada aktiva riilnya atau bahkan mengalami penurunan nilai karena perusahaan tersebut tidak mampu menangkap peluang investasi yang ada.

Keputusan dalam berinvestasi merupakan suatu tindakan yang dilakukan berbagai pihak untuk mendapatkan keuntungan secara materi dalam jangka waktu yang cukup panjang. Keputusan ini, didasarkan pada pertimbangan di performa perusahaan di masa lalu yang dikondisikan dalam sebuah metode penilaian, sehingga menjadi sebuah check point yang dijadikan dasar prediksi perusahaan tersebut di masa yang akan datang. Perusahaan di klasifikasikan menjadi dua yaitu perusahaan tumbuh dan tidak tumbuh. Diperlukan berbagai macam pertimbangan-pertimbangan ini tentunya membutuhkan berbagai macam informasi.

Investment Opportunity Set (IOS) masih digunakan sebagai salah satu indikator bagi investor untuk mengetahui kemungkinan tumbuh atau tidaknya suatu perusahaan, sehingga berefek secara langsung pada keputusan perusahaan dalam berinvestasi. Investment Opportunity Set (IOS) berpengaruh pada manajer, pemilik, investor, ataupun kreditor terhadap perusahaan itu sendiri, penelitian yang berkelanjutan terus dilakukan untuk meningkatkan akurasi dari IOS, tentunya dengan menambah berbagai macam kombinasi proksi dan juga pengkondisian dari perusahaan tersebut, dengan tujuan memudahkan berbagai pihak dalam membuat keputusan. Penelitian mengenai IOS ini lebih banyak dikaitkan dengan hubungan kebijakan pendanaan dan dividen. 
Himmatul Ulyah: Kebijakan Pendanaan dan Deviden

Kebijakan pendanaan adalah kebijakan yang berhubungan dengan penentuan sumber dana yang akan digunakan, penentuan perimbangan pembelanjaan yang optimal, dan perusahaan menggunakan sumber dana dari dalam perusahaan atau akan mengambil dana dari luar perusahaan. Salah satu tolak ukur pertumbuhan perusahaan ditunjukkan oleh besarnya investasi. Oleh karena itu, diduga bahwa perusahaan yang memiliki potensi tumbuh tinggi memiliki kebijakan pendanaan yang berbeda dengan perusahaan yang memiliki potensi tumbuh rendah. Perusahaan bertumbuh membutuhkan dana yang besar untuk membiayai investasinya. Perusahaan harus membuat keputusan pendanaan, dimana perusahaan cukup menggunakan dana yang bersumber dari dalam perusahaan atau mengambil dana dari luar perusahaan. Perusahaan yang mempunyai investasi tinggi akan menyebabkan hutang menjadi tinggi. Hal tersebut terjadi karena hutang yang tinggi digunakan untuk membiayai kesempatan investasi.

Kebijakan dividen merupakan kebijakan yang menyangkut keputusan untuk membagikan laba atau menahannya guna diinvestasikan kembali dalam perusahaan. Tingkat pertumbuhan perusahaan berpengaruh terhadap pembayaran dividen. Perusahaan yang pertumbuhannya tinggi mempunyai kesempatan yang memungkinkan untuk membayar dividen yang lebih rendah karena mereka mempunyai kesempatan yang menguntungkan dalam mendanai investasinya secara internal, sehingga tidak terdorong untuk membayar bagian laba yang lebih besar kepada para investor. Sebaliknya perusahaan yang pertumbuhannya rendah berusaha manarik dana dari luar untuk mendanai investasinya dengan mengorbankan sebagian besar labanya dalam bentuk dividen.

Beberpa peneliti keuangan sudah mengembangkan penelitian tentang Investment Opportunity Set (IOS). Diawali oleh Smith dan Watts (1992), yang mengusulkan proposisi mengenai asosiasi antara set peluang investasi atau investment opportunity set perusahaan dengan kebijakan pendanaan, dividen, dan kompensasi. Mereka menggunakan data yang disusun berdasarkan level industri untuk mendukung hipotesis mereka. Temuan mereka menunjukkan bahwa perusahaan dengan peluang pertumbuhan yang tinggi: menggunakan hutang yang lebih kecil dalam struktur modalnya, membayar dividen ebih kecil, dan membayar kompensasi eksekutif lebih besar.

Berdasarkan latar belakang masalah yang ada, maka tujuan penelitian ini adalah untuk mengetahui sejauh mana proksi IOS dapat menghasilkan perbedaan bagi perusahaan manufaktur dalam penetapan kebijakan pendanaan dan kebijakan dividen. Maka peneliti 
Ihtiyath Vol. 2 No. 1 September 2018

bermaksud untuk melakukan penelitian dengan judul “Kebijakan Pendanaan dan Dividen Dengan Pendekatan Insvestment Opportunity Set “

\section{KERANGKA TEORITIS DAN HIPOTESIS Kebijakan Pendanaan}

Dalam rangka mengukur resiko, fokus perhatian kreditor jangka panjang terutama ditunjukan pada prospek laba dan perkiraan arus kas. Meskipun demikian, mereka tidak dapat mengabaikan pentingnya tetap mempertahankan keseimbangan antara proporsi aktiva yang didanai oleh kreditor dan didanai oleh pemilik perusahaan. Keseimbangan proporsi antara aktiva yang didanai oleh kreditor dan yang didanai oleh pemerintah diukur dengan ratio debt to equity.

Dimana rasio ini merupakan presentase dari hutang relatif terhadap jumlah ekuitas yang dimiliki perusahaan. Ratio debt to equity ini dapat memberikan gambaran mengenai struktur modal yang dimiliki perusahaan sehingga dapat dilihat tingkat risiko tak tertagihnya hutang. Semakin besar proporsi hutang relatif terhadap ekuitas maka semakin besar pula risiko perusahaan. kreditor jangka panjang pada umumnya lebih menyukai angka rasio debt to equity yang kecil. Makin kecil rasio ini, berarti semakin besar jumlah aktiva yang didanai oleh pemilik perusahaan, dan semakin besar penyangga risiko kreditor (Adi Prasetyo. 2000).

Suad Husnan (2000:277-278) menyatakan bahwa keputusan pendanaan perusahaan menyangkut keputusan tentang bentuk dan komposisi pendanaan yang akan dipergunakan oleh perusahaan. Secara rinci pertanyaan-pertanyaan yang perlu dijawab dalam masalah keputusan pendanaan adalah:

1. Berapa banyak hutang dan modal sendiri yang akan dipergunakan. keputusan ini akan menentukan rasio hutang terhadap modal sendiri. Beberapa jenis perusahaan berani menggunakan rasio hutang yang cukup tinggi, sedangkan lainnya cenderung konservatif.

2. Bagaimana tipe hutang dan modal sendiri yang dipergunakan. Apakah hutang akan ditarik dalam bentuk hutang jangka panjang, jangka pendek, dan hutang yang dikonversikan menjadi modal sendiri. Apakah modal sendiri akan diperoleh dari menahan laba, ataukah lebih baik menerbitkan saham baru. 
Himmatul Ulyah: Kebijakan Pendanaan dan Deviden

3. Kapan akan menghimpun dana dalam bentuk hutang/modal sendiri. Pada saat pasar modal sedang membaik (bullish), apakah sebaiknya menerbitkan obligasi ataukah saham, bagaimana kalau keadaan pasar modal sedang lesu (bearish).

\section{Kebijakan Dividen}

Kebijakan deviden mempengaruhi baik pembelanjaan jangka panjang atupun penghasilan yang dibagikan kepada pemegang saham, maka perusahaan memiliki dua kemungkinan sudut pandang untuk membayar dividen:

1. Sebagai Keputusan Pembelanjaan Jangka Panjang

Dengan pendekatan ini, semua laba sesudah pajak yang diperoleh perusahaan dapat dipandang sebagai sumber dana jangka panjang. Suatu pengumuman dividen kas mengurangi jumlah dana yang tersedia untuk membelanjai pertumbuhan, membatasi pertumbuhan, atau memaksa perusahaan memperoleh sumber dana yang lain.

2. Sebagai Suatu Keputusan Kesejahteraan Maksimum

Dengan pendekatan ini perusahaan mengakui bahwa pembayaran dividen mempunyai pengaruh terhadap harga pasar saham biasa. Perusahaan harus memaksimumkan rasa kesejahteraan dengan mendeklarasikan dividen yang cukup untuk memenuhi harapan investor dan pemegang saham.

Dengan demikian kebijakan dividen merupakan keputusan yang penting karena dapat berpengaruh terhadap nilai perusahaan. Kebijakan dividen yang tepat dapat berimplikasi terhadap kekayaan para pemegang saham perusahaan. Kebijakan dividen yang optimal adalah kebijakan yang menciptakan keseimbangan diantara dividen saat ini dan pertumbuhan dimasa mendatang sehingga memaksimumkan harga saham (Brigham dan Houston, 1994:198).

\section{Investment Opportunity Set (IOS)}

Mayers dalam Smith dan Watts yang di kutip dari Subekti dan Kusuma (2000) menyatakan bahwa yang dimaksud dengan perusahaan adalah kombinasi dari nilai aktiva rill (asset in the place) dengan pilihan investasi dimasa yang akan datang. Menurut Gaver dan Gaver dalam Subekti dan Kusuma (2000) opsi investasi masa depan tidak hanya semata-mata ditunjukan dengan adanya proyek-proyek yang didukung dengan adanya kegiatan riset dan hanya pengembangan saja, akan tetapi juga dengan adanya kemampuan sebuah pe- 
Ihtiyath Vol. 2 No. 1 September 2018

rusahaan untuk mengeksploitasi kesempatan untuk mengambil keuntungan dibandingkan dengan perusahaan lain yang memiliki kelompok industri yang sama.Kemampuan perusahaan yang lebih tinggi ini memiliki suatu sifat yang tidak bisa untuk diobservasi.

Berdasarkan pada penelitian tersebut para peneliti telah mengembangkan suatu proksi pertumbuhan perusahaan menjadi Investment Opportunity Set (IOS) sesuai dengan tujuan dan jenis data yang tersedia dalam sebuah penelitian. Kemudian Investment Opportunity Set (IOS) akan dijadikan sebagai dasar untuk mengklasifikasi berdasarkan pertumbuhan perusahaan dimasa yang akan datang dimana apakah sebuah perusahaan tersebut termasuk dalam golongan perusahaan yang berpotensi tumbuh tinggi atau perusahaan yang berpotensi tumbuh rendah.

\section{Alternatif Proksi Investment Opportunity Set (IOS)}

Ada beberapa proksi yang dapat digunakan dalam bidang akuntansi dan keuangan untuk memahami pemikiran IOS (Myers,1997 dalam Kallapur dan Trombley, 1999).

Proksi-proksi tersebut dapat digolongkan menjadi tiga jenis yaitu:

1. Proksi Berbasis Harga (Price-based proxies)

Proksi ini mendasarkan pada perbedaan antara aset dan nilai perusahaan, oleh karena itu proksi ini sangat tergantung pada harga saham (Hartono,1999). Proksi ini percaya pada gagasan bahwa prospek yang tumbuh dari suatu perusahaan sebagian dinyatakan dalam harga yang relatif lebih tinggi dibandingkan dengan aktiva rillnya (assets in place). Oleh kerena itu proksi ini sangat tergantung pada harga saham (hArtono, 1999). Rasio-rasio yang telah digunakan dalam beberapa penelitian yang berkaitan dengan proksi harga adalah sebagai berikut:

a. Market to book value equity (MKTBKEQ)

b. Tobin's Q (Skinner, 1993; Kallapur dan Trombley 1999; dan Denis 1994)

c. Ratio firm value to property, plant, and equipment (PPE/V)

d. Ratio of depreciation expense to value (DEP/V), (Smith dan Watts 1992; Kallapur dan Trombley 1999; Ho, Lam, dan Sami 1999; Jones dan Sharma, 2001).

e. Market to book value of assets (MKTBKASS)

f. Price to earning ratio (PER)

2. Proksi Berbasis Investasi (investment-based proxies) 
Himmatul Ulyah: Kebijakan Pendanaan dan Deviden

Proksi ini percaya pada gagasan bahwa suatu level kegiatan investasi yang tinggi berkaitan secara positif dengan nilai IOS suatu perusahaan (Kallapur dan Trombley,1999). Perusahaan dengan IOS yang tinggi juga mempunyai tingkat investasi yang sama tinggi, yang dikonversi menjadi aset yang dimiliki (Kallapur dan Trombley, 1999). Rasio-rasio yang sering digunakan dalam penelitian ini adalah:
a. Ratio capital expenditure to book value asset (CAPBVA)
b. Ratio capital expenditure to market value asset (CAPMVA)
c. Ratio investment to net sales (IONS)

3. Proksi Berbasis Varian (variance measure)

Proksi ini percaya pada gagasan bahwa suatu opsi akan menjadi lebih bernilai jika menggunakan variabilitas ukuran untuk memperkirakan besarnya opsi yang tumbuh, seperti variabilitas return yang mendasari peningkatan aktiva. Ukuran-ukuran yang dapat digunakan dalam penelitian ini adalah:

a. Varian return (VARRET), (Gaver dan Gaver 1993, Smith dan Watts 1992)

b. Beta aset (BETA), (Skinner 1993, Kallapur dan Trombley 1999)

\section{Perumusan Hipotesis}

\section{Hubungan Antara IOS (Investment Opportunity Set) dengan Kebijakan Pendanaan}

Smith dan Watts (1992) menemukan adanya bukti bahwa pada perusahaan yang memiliki kesempatan untuk tumbuh lebih besar memiliki rasio debt to equity yang lebih kecil dalam kebijakan struktur modalnya karena pendanaan modal sendiri (equity financing) cenderung untuk mengurangi masalah-masalah agensi yang potensial berasosiasi dengan eksistensi hutang yang berisiko dalam struktur modalnya (underinvestment). Perusahaan yang tumbuh memiliki leverage yang lebih kecil dari pada perusahaan yang tidak tumbuh dengan pertimbangan untuk mengurangi risiko usahanya, apabila terjadi kegagalan sehingga tidak mampu membayar bunga hutang.

Kim (1982) menyatakan bahwa salah satu tolak ukur struktur modal yang optimal ditunjukan dengan leverage yang kecil perusahaan cenderung mengurangi risikonya. Sehingga secara sederhana dapat diduga perusahaan yang tumbuh mempunyai leverage yang lebih kecil dari pada perusahaan yang tidak tumbuh, pernyataan tentang hal ini juga didukung oleh hasil penelitian yang dilakukan oleh Gaver dan Gaver (1993), Skinnere (1993), Kallapur dan Trombley (1999), Imam Subekti dan Indra Wijaya Kusuma (2000), Tettet Fijrijanti dan Jogiyanto Hartono (2000), dan Adi Prasetyo (2000) dimana hasil penelitian mereka konsisten dengan teori biaya kontrak yang memiliki tujuan untuk me- 
maksimalisasi keuntungan dan nilai perusahaan.

$\mathrm{H}_{1}$ : Terdapat perbedaan kebijakan pendanaan antara perusahaan manufaktur yang berpotensi tumbuh tinggi dan perusahaan yang berpotensi tumbuh rendah dengan menggunakan Investment Opportunity Set

\section{Hubungan Antara IOS (Investment Opportunity Set) dengan Kebijakan Deviden}

Dalam hal kebijakan dividen masih terdapat beberapa perbedaan dari hasil penelitian. Peneliti yang menyatakan bahwa pembayaran dividen lebih besar pada perusahaan tumbuh dijelaskan bahwa hipotesis sinyal menyatakan bahwa perusahaanyang berkualitas tinggi akan membayar dividen lebih tinggi (Miller dan Rock, 1985) dan juga adanya disparitas informasi menyebabkan perusahaan yang memiliki pilihan pertumbuhan kecil akan membayar dividen lebih tinggi sebagai sinyal bahwa kondisi perusahaan baik (Bhattacharya, 1979 dalam Smith dan Watts,1993).

Disisi lain terdapat pernyataan yang menyatakan bahwa nilai dividen lebih rendah pada perusahaan yang tumbuh dengan menggunakan teori pembandingannya free cash flow yang menyatakan bahwa perusahaan yang tumbuh memberikan dividen yang lebih rendah dari pada perusahaan yang yidak tumbuh dikarenakan laba ditahan yang dihasilkan perusahaan sebagian besar dialokasikan untuk melakukan ekspansi, sehingga proporsi pembagian dividen berkursng. Pernyataan ini didukung oleh hasil penelitian Jensen (1986), Gaver dan Gaver (1993), Kallapur dan Trombley (1999).

Pernyataan diatas menurut Barclay dan Smith (1998, dalam Subekti dan Kusuma 2001) juga konsisten dengan prediksi teori contracting yang mengisyaratkan bahwa perusahaan yang memiliki opsi untuk tumbuh lebih besar akan memiliki hutang yang lebih sedikit dikarenakan perusahaan lebih mengutamakan solusi atau masalah yang berkaitan dengan hutangnya, yang dalam hal ini mengurangi nilai jumlah dividen yang dikeluarkan oleh perusahaan. Studi empiris yang mendukung hubungan teori contracting dengan kebijakan dividen adalah Jesen (1986), Gaver dan Gaver (1993), Kallapur Trombley (1999), Imam Subekti dan Indra Wijaya Kusuma (2001), dan Tettet Fijrijanti dan Jogiyanto Hartono (2000).

$\mathrm{H}_{2}$ : Terdapat perbedaan kebijakan dividen antara perusahaan manufaktur yang berpotensi tumbuh tinggi dan perusahaan yang berpotensi tumbuh rendah dengan meng- 
gunakan Investment Opportunity Set.

\section{METODE PENELITIAN}

Jenis Penelitian

Jenis penelitian yang akan dilakukan pada skripsi ini tergolong sebagai hypotesis testing. Studi yang termasuk dalam pengujian hipotesis biasanya menjelaskan sifat hubungan tertentu, atau menetukan perbedaan antar kelompok atau kebebasan (independensi) dua atau lebih faktor dalam suatu situasi (uma sekaran, 2006:162). Hypotesis testing merupakan suatu penelitian yang sudah memiliki kejelasan dan gambaran, pengujian hipotesis dimaksudkan untuk menjelaskan hubungan kausal antara variabel-variabel penelitian. Objek penelitian menjelaskan tentang apa atau siapa yang menjadi objek penelitian juga dimana dan kapan penelitian dilakukan. bisa juga ditambahkan hal-hal lain jika dianggap perlu (Husein Umar, 2003:303). Objek penelitian ini adalah perusahaan manufaktur yang listing di bursa efek indonesia tahun 2014-2017.

\section{Populasi dan Sampel}

Menurut Sugiyono (2011:117) populasi adalah wilayah generalisasi yang terdiri atas: obyek/ subyek yang mempunyai kualitas dan karakteristik tertentu yang ditetapkan oleh peneliti untuk dipelajari dan kemudian ditarik kesimpulannya. Populasi dalam penelitian ini adalah seluruh perusahaan manufaktur yang terdaftar di Bursa Efek Indonesia (BEI) sebanyak 152dengan periode pengamatan dilakukan dari tahun 2014-2017 sebanyak 39 perusahaan. Dalam penelitian ini pengambilan sampel dilakukan dengan metode purposive sampling, yaitu sampel dipilih atas dasar kesesuaian karakteristik sampel dengan kriteria pemilihan sampel yang telah ditentukan. kriteria-kriteria dalam pengambilan sampel dalam penelitian ini harus memenuhi ketentuan-ketentuan sebagai berikut:

1. Perusahaan manufaktur yang terdaftar di BEI sejak 2009 sampai 2012 danmempublikasikan keuangan tahunan secara berturut-turut selama tahun 2014-2017.

2. Tidak memiliki laba dan saldo ekuitas negatif selama tahun 2009, 2010, 2011, dan 2012.

3. Perusahaan manufaktur memiliki data atau informasi keuangan yang lengkap.

\section{Teknik Analisis Data}

Teknik analisis data bertujuan untuk menyampaikan dan membatasi penemuan-penemuan hingga menjadi data yang teratur. Investment Opportunity Set sebagai set kesempatan investasi memerlukan proksi-proksi untuk menjelaskan, yaitu menggunakan nilai Price Earnings Ratio (PER). 
Ihtiyath Vol. 2 No. 1 September 2018

\section{Pengujian Hipotesis}

Pengujian untuk hipotesis yaitu menggunakan uji beda mean. Uji beda mean digunakan untuk membandingkan rata-rata dua kelompok apakah terdapat perbedaan antara keduanya. Apabila perbandingan kedua kelompok rata-rata tersebut taraf signifikansinya kurang dari 0,05 dapat dikatakan bahwa kedua kelompok tersebut berbeda secara signifikan.

Sebelum melakukan pengujian data rasio kebijakan pendanaan (debt to book value of equity) dan rasio kebijakan dividen (dividend yield) setiap perusahaan pada tahun 2009, 2010, 2011, 2012 akan dirata-rata, setelah itu dilakukan uji statistik untuk melihat perbedaan rata-rata kedua variabel tersebut dari kelompok perusahaan yang tumbuh dan yang tidak tumbuh. Untuk mengetahui apakah ada perbedaan itu, maka akan dilakukan metode one way ANOVA bila data terdistribusi normal dan bila data tidak terdistribusi normal dilakukan uji statistik non parametrik U Mann-Whitney yang tidak memerlukan asumsi distribusi terhadap data.

Uji statistik U Mann-Whitney adalah salah satu uji non parametrik yang sangat kuat dan merupakan alternatif dari uji parametrik $t$-test, jika peneliti ingin menghindari asumsi $t$-test atau pengukuran dalam data lebih lemah dibandingkan skala interval.

\section{HASIL DAN PEMBAHASAN HASIL PENELITIAN}

Deskripsi hasil data Price Earnings Ratio (PER) pada perusahaan manufaktur yang berpotensi tumbuh tinggi dan perusahaan yang berpotensi tumbuh rendah Tahun 2014 - 2017 sebagaimana terlihat pada tabel berikut.

\begin{tabular}{|l|c|c|c|}
\hline \multicolumn{1}{|c|}{ Keterangan } & $\begin{array}{c}\text { Rasio Ter- } \\
\text { endah }\end{array}$ & $\begin{array}{c}\text { Rasio Tert- } \\
\text { inggi }\end{array}$ & Rata-rata \\
\hline PER Potensi tumbuh Tinggi & 10,19 & 292,18 & 23,8984 \\
\hline PER Potensi tumbuh Rendah & $-16,75$ & 9,95 & 5,8910 \\
\hline
\end{tabular}

Sumber : Data Diolah (2018)

Kebijakan pendanaan yang diukur dengan menggunakan rasio PER pada perusahaan manufaktur yang terdaftar di bursa efek Indonesia menunjukkan bahwa pada perusahaan manufaktur yang berpotensi tumbuh tinggi memiliki nilai rasio terendah adalah sebesar 10,19\% yaitu pada PT Energi Persada Tbk pada tahun 2014. Sedangkan nilai rasio tertinggi adalah sebesar 292,18\% yaitu pada perusahaan PT Rigs Tender Tbk pada tahun 
Himmatul Ulyah: Kebijakan Pendanaan dan Deviden

2014. Nilai rata-rata kebijakan pendanaan pada perusahaan manufaktur tersebut adalah sebesar 23,8984 .

Kebijakan pendanaan yang diukur dengan menggunakan rasio PER pada perusahaan manufaktur yang terdaftar di bursa efek Indonesia menunjukkan bahwa pada perusahaan manufaktur yang berpotensi tumbuh rendah memiliki nilai rasio terendah adalah sebesar $-16,75 \%$ yaitu pada PT Sorini Coorporation Tbk pada tahun 2017. Sedangkan nilai rasio tertinggi adalah sebesar 9,95\% yaitu pada perusahaan PT Tunas Ridean Tbk pada tahun 2017. Nilai rata-rata kebijakan pendanaan pada perusahaan manufaktur tersebut adalah sebesar 5,8910.

\section{Kebijakan Pendanaan}

Deskripsi hasil data mengenai kebijakan pendanaan pada perusahaan manufaktur yang berpotensi tumbuh tinggi dan perusahaan yang berpotensi tumbuh rendah Tahun 2014 2017 sebagaimana terlihat pada tabel berikut.

\begin{tabular}{|l|c|c|c|}
\hline \multicolumn{1}{|c|}{ Keterangan } & $\begin{array}{c}\text { Rasio Ter- } \\
\text { endah }\end{array}$ & $\begin{array}{c}\text { Rasio Tert- } \\
\text { inggi }\end{array}$ & Rata-rata \\
\hline DER Potensi tumbuh Tinggi & 0,14 & 4,44 & 0,9074 \\
\hline DER Potensi tumbuh Rendah & 0,17 & 17,75 & 1,6689 \\
\hline
\end{tabular}

Sumber : Data Diolah (2018)

Kebijakan pendanaan yang diukur dengan menggunakan rasio DER pada perusahaan manufaktur yang terdaftar di bursa efek Indonesia menunjukkan bahwa pada perusahaan manufaktur yang berpotensi tumbuh tinggi memiliki nilai rasio terendah adalah sebesar 0,14\% yaitu pada PT Sumi Indo Kabel Tbk pada tahun 2014. Sedangkan nilai rasio tertinggi adalah sebesar 4,44\% yaitu pada perusahaan PT Multi Bintang Indonesia Tbk pada tahun 2015. Nilai rata-rata kebijakan pendanaan pada perusahaan manufaktur tersebut adalah sebesar 0,9074 .

Kebijakan pendanaan yang diukur dengan menggunakan rasio DER pada perusahaan manufaktur yang terdaftar di bursa efek Indonesia menunjukkan bahwa pada perusahaan manufaktur yang berpotensi tumbuh rendah memiliki nilai rasio terendah adalah sebesar 0,17\% yaitu pada PT Lion Metal Tbk pada tahun 2016. Sedangkan nilai rasio tertinggi adalah sebesar 17,75\% yaitu pada perusahaan PT Bumi Resource Tbk pada tahun 2017. Nilai rata-rata kebijakan pendanaan pada perusahaan manufaktur tersebut adalah 
sebesar 1,6689 .

\section{Kebijakan Deviden}

Deskripsi hasil data mengenai kebijakan deviden pada perusahaan manufaktur yang berpotensi tumbuh tinggi dan perusahaan yang berpotensi tumbuh rendah Tahun 2014 2017 sebagaimana terlihat pada tabel berikut.

\begin{tabular}{|l|c|c|c|}
\hline \multicolumn{1}{|c|}{ Keterangan } & $\begin{array}{c}\text { Rasio Ter- } \\
\text { endah }\end{array}$ & $\begin{array}{c}\text { Rasio Tert- } \\
\text { inggi }\end{array}$ & Rata-rata \\
\hline DER Potensi tumbuh Tinggi & 0,01 & 22,30 & 3,8503 \\
\hline DER Potensi tumbuh Rendah & 0,01 & 21,05 & 5,4821 \\
\hline
\end{tabular}

Sumber : Data Diolah (2018)

Kebijakan deviden yang diukur dengan menggunakan rasio DY pada perusahaan manufaktur yang terdaftar di bursa efek Indonesia menunjukkan bahwa pada perusahaan manufaktur yang berpotensi tumbuh tinggi memiliki nilai rasio terendah adalah sebesar 0,01\% yaitu pada PT Jaya Pari Steel Tbk tahun 2014, 2015, dan 2017, pada PT Ramayana Tbk tahun 2015, pada PT Multi Bintang Tbk tahun 2016 dan 2017, dan pada PT Sorini Coorporation Tbk tahun 2016. Sedangkan nilai rasio tertinggi adalah sebesar 22,30\% yaitu pada PT Multi Bintang Indonesia Tbk tahun 2016. Nilai rata-rata kebijakan pendanaan pada perusahaan manufaktur tersebut adalah sebesar 3,8503.

Kebijakan pendanaan yang diukur dengan menggunakan rasio DER pada perusahaan manufaktur yang terdaftar di bursa efek Indonesia menunjukkan bahwa pada perusahaan manufaktur yang berpotensi tumbuh rendah memiliki nilai rasio terendah adalah sebesar 0,01\% yaitu pada PT Igarjaya Tbk tahun 2015, pada PT Rigs Tender Tbk tahun 2015 dan 2017, pada PT Jaya Pari Steel Tbk tahun 2016, pada PT Trias Sentosa Tbk tahun 2016, dan pada PT Bumi Resource Tbk tahun 2017. Sedangkan nilai rasio tertinggi adalah sebesar 21,05\% yaitu pada PT Igarjaya Tbk tahun 2016. Nilai rata-rata kebijakan pendanaan pada perusahaan manufaktur tersebut adalah sebesar 5,4821.

\section{Perbedaan Kebijakan Pendanaan antara Perusahaan Manufaktur yang Berpotensi Tumbuh Tinggi dan Perusahaan yang Berpotensi Tumbuh Rendah}

Hasil pengukuran perbedaan kebijakan pendanaan antara perusahaan manufaktur yang berpotensi tumbuh tinggi dan perusahaan yang berpotensi tumbuh rendah dapat dilihat 
pada tabel berikut.

\begin{tabular}{|c|c|c|c|c|c|}
\hline No. & Periode & $\begin{array}{c}\text { Mean } \\
\text { Rank }\end{array}$ & $\begin{array}{c}\text { Mann } \\
\text { Whitney }\end{array}$ & Sig. & Keterangan \\
\hline 1. & Potensi tumbuh Tinggi & 71,19 & & \multirow{2}{*}{0,014} & $\begin{array}{l}\text { Terdapat perbe- } \\
\text { daan yang ber- } \\
\text { makna }\end{array}$ \\
\hline 2. & Potensi tumbuh Rendah & 89,29 & & & \\
\hline
\end{tabular}

Sumber : Data Diolah (2018)

Berdasarkan tabel tersebut dapat dilihat bahwa nilai mean rank kebijakan pendanaan pada kelompok data perusahaan yang memiliki potensi tumbuh tinggi adalah sebesar $71,19 \%$ sedangkan mean rank kebijakan pendanaan pada kelompok data perusahaan yang memiliki potensi tumbuh rendah adalah sebesar $82,29 \%$. Hal ini menunjukkan bahwa perusahaan yang memiliki potensi tumbuh rendah memiliki risiko kebijakan pendanaan yang lebih besar dibandingkan perusahaan yang memiliki potensi tumbuh tinggi. Adapun perbedaan kebijakan pendanaan antara perusahaan manufaktur yang berpotensi tumbuh tinggi dan perusahaan yang berpotensi tumbuh rendah dihasilkan nilai signifikan sebesar 0,014 . Nilai tersebut menunjukkan perbedaan yang signifikan, berdasarkan nilai Asymp. Sig (2-tailed) yang lebih rendah dari tingkat alpha 0,05.

Hasil analisis tersebut menjawab hipotesis penelitian, dimana pertama ( $\mathrm{H} 1)$ yang menyatakan bahwa terdapat perbedaan kebijakan pendanaan antara perusahaan manufaktur yang berpotensi tumbuh tinggi dan perusahaan yang berpotensi tumbuh rendah dengan menggunakan Investment Opportunity Set adalah diterima.

\section{Perbedaan Kebijakan Deviden antara Perusahaan Manufaktur yang Berpotensi Tum- buh Tinggi dan Perusahaan yang Berpotensi Tumbuh Rendah}

Hasil pengukuran perbedaan kebijakan deviden antara perusahaan manufaktur yang berpotensi tumbuh tinggi dan perusahaan yang berpotensi tumbuh rendah dapat dilihat pada tabel berikut. 
Ihtiyath Vol. 2 No. 1 September 2018

\begin{tabular}{|c|c|c|c|c|c|}
\hline No. & Periode & $\begin{array}{l}\text { Mean } \\
\text { Rank }\end{array}$ & $\begin{array}{c}\text { Mann } \\
\text { Whitney }\end{array}$ & Sig. & Keterangan \\
\hline 1. & Potensi tumbuh Tinggi & 70,38 & & & Terdapat perbe- \\
\hline 2. & Potensi tumbuh Rendah & 90,49 & 2174,000 & 0,006 & $\begin{array}{l}\text { daan yang ber- } \\
\text { makna }\end{array}$ \\
\hline
\end{tabular}

Sumber : Data Diolah (2018)

Berdasarkan tabel tersebut dapat dilihat bahwa nilai mean rank kebijakan deviden pada kelompok data perusahaan yang memiliki potensi tumbuh tinggi adalah sebesar 70,38\% sedangkan mean rank kebijakan deviden pada kelompok data perusahaan yang memiliki potensi tumbuh rendah adalah sebesar 90,49\%. Hal ini menunjukkan bahwa perusahaan yang memiliki potensi tumbuh rendah memiliki kebijakan deviden yang lebih besar dibandingkan perusahaan yang memiliki potensi tumbuh tinggi. Adapun perbedaan kebijakan pendanaan antara perusahaan manufaktur yang berpotensi tumbuh tinggi dan perusahaan yang berpotensi tumbuh rendah dihasilkan nilai signifikan sebesar 0,006. Nilai tersebut menunjukkan perbedaan yang signifikan, berdasarkan nilai Asymp. Sig (2-tailed) yang lebih rendah dari tingkat alpha 0,05.

Hasil analisis tersebut menjawab hipotesis penelitian, dimana kedua ( $\left.\mathrm{H}_{2}\right)$ yang menyatakan bahwa terdapat perbedaan kebijakan deviden antara perusahaan manufaktur yang berpotensi tumbuh tinggi dan perusahaan yang berpotensi tumbuh rendah dengan menggunakan Investment Opportunity Set adalah diterima.

\section{PEMBAHASAN}

\section{Kebijakan Pendanaan}

Hasil penelitian ini menunjukan bahwa kebijakan pendanaan memiliki perbedaan yang signifikan pada perusahaan tumbuh dan perusahaan tidak tumbuh. Hasil ini mendukung penelitian sebelumnya. Dalam hal ini DER pada perusahaan tumbuh signifikan lebih tinggi dibanding perusahaan yang tidak tumbuh. Hal ini dikarenakan bahwa pada perusahaan yang tumbuh akan memerlukan dana yang lebih tinggi dalam mendanai beberapa aktivitas atau proyek yang dilakukan oleh perusahaan.

Suad Husnan (2000:277-278) menyatakan bahwa keputusan pendanaan perusahaan menyangkut keputusan tentang bentuk dan komposisi pendanaan yang akan dipergunakan oleh perusahaan. Kebutuhan akan dana yang besar tersebut oleh perusahaan nampakn- 
Himmatul Ulyah: Kebijakan Pendanaan dan Deviden

ya akan sulit untuk ditutup dengan hanya mengandalkan modal sendiri, sehingga perusahaan akan menggunakan atau membuat kontrak hutang dengan pihak ketiga. Sebaliknya pihak ketiga atau kreditor dengan pertimbangan akan pertumbuhan perusahaan akan bersedia memberikan pinjaman yang dimaksudkan. Dimana rasio ini merupakan presentase dari hutang relatif terhadap jumlah ekuitas yang dimiliki perusahaan.

Lebih rendahnya rasio DER ini dikarenakan pada perusahaan yang memiliki potensi tumbuh tinggi menunjukkan bahwa perusahaan tersebut semakin dipercaya oleh investor. Kepercayaan yang diperoleh dari investor tersebut ditunjukkan dengan semakin meningkatnya harga saham perusahaan. Peningkatan harga saham perusahaan akan mengakibatkan semakin meningkatnya nilai pasar saham perusahaan, sehingga nilai pasar ekuitas juga meningkat. Peningkatan nilai pasar ekuitas ini menjadikan rasio hutang dibagi dengan nilai pasar ekuitas semakin rendah.

\section{Kebijakan Dividen}

Hasil penelitian ini mendapatkan bahwa Kebijakan dividen memiliki perbedaan yang signifikan pada perusahaan tumbuh dan perusahaan tidak tumbuh. Hasil ini mendukung penelitian sebelumnya. Menurut Sartono (1998:369-389), menyatakan bahwa kebijakan dividen adalah keputusan apakah laba yang diperoleh perusahaan akan dibagikan kepada pemegang saham sebagai dividen atau akan ditahan dalam bentuk laba ditahan guna pembiayaan investasi dimasa mendatang. Apabila perusahaan memilih untuk membagikan laba sebagai dividen maka akan mengurangi laba yang ditahan dan kemudian akan mengurangi total sumber daya internal financing, maka kemampuan pembentukan dana intern akan semakin besar. Dengan asumsi tersebut maka kebijakan dividen ini harus dianalisa dalam kaitannya dengan keputusan pembelajaran atau penentuan struktur modal secara keseluruhan dan faktor - faktor penting yang mempengaruhi kebijakan dividen adalah kesempatan investasi yang tersedia, biaya modal alternatif, preferensi pemegang saham untuk menerima pendapatan saat ini atau menerimanya dimasa yang akan datang.

Semakin cepat tingkat pertumbuhan perusahaan, maka semakin besar kebutuhan untuk membiayai pertumbuhan perusahaan tersebut. Semakin besar kebutuhan dana di waktu mendatang untuk membiayai pertumbuhannya, perusahaan tersebut biasanya lebih senang untuk menahan pendapatannya daripada dibayarkan sebagai dividen kepada para 
Ihtiyath Vol. 2 No. 1 September 2018

pemegang saham dengan mengingat batasan-batasan biayanya. Dengan demikian dapat dikatakan bahwa semakin cepat tingkat pertumbuhan perusahaan semakin besar dana yang dibutuhkan, semakin besar kesempatan memperoleh untung, semakin besar bagian dari pendapatan yang ditahan dalam perusahaan, sehingga semakin rendah pembagian dividennya.

Kinerja keuangan merupakan gambaran kondisi keuangan perusahaan pada suatu periode tertentu yang melibatkan aspek dana serta diukur dengan indikator kecukupan modal, likuiditas, dan profitabilitas. Informasi kinerja keuangan diperlukan untuk menilai perubahan potensial sumber daya ekonomi, yang mungkin dikendalikan di masa depan dan untuk memprediksi kapasitas produksi dari sumber daya yang ada. Sedangkan laporan keuangan yang telah dianalisis sangat diperlukan pemimpin perusahaan atau manajemen untuk dijadikan sebagai alat pengambilan keputusan lebih lanjut untuk masa yang akan datang. Evaluasi kineja keuangan dapat dilakukan menggunakan analisis laporan keuangan. Dimana analisis laporan keuangan dapat dilakukan menggunakan rasio keuangan. Rasio keuangan merupakan alat analisis keuangan yang paling sering digunakan.

Rasio keuangan menghubungkan berbagai perkiraan yang terdapat pada laporan keuangan sehingga kondisi keuangan dan hasil operasi suatu perusahaan dapat diinterpretasikan. Debt to Equity Ratio merupakan salah satu rasio keuangan yang tergolong kelompok rasio solvabilitas. Debt to Equity Ratio adalah rasio yang menggunakan hutang dan modal untuk mengukur besarnya rasio. Debt to Equity Ratio merupakan rasio yang dipergunakan untuk mengukur tingkat penggunaan utang terhadap total shareholder's equity yang dimiliki perusahaan. Debt to Equity Ratio menunjukan persentase penyediaan dana oleh pemegang saham terhadap pemberi pinjaman.

Semakin tinggi rasio, semakin rendah pendanaan perusahaan yang disediakan oleh pemegang saham. Dari perspektif kemampuan membayar kewajiban jangka panjang, semakin rendah rasio akan semakin baik kemampuan perusahaan dalam membayar kewajiban jangka panjangnya. Semakin tinggi DER menunjukkan komposisi total hutang (jangka pendek dan jangka panjang) semakin besar dibanding dengan total modal sendiri, sehingga berdampak semakin besar beban perusahaan terhadap pihak luar (kreditur). Meningkatnya beban terhadap kreditur menunjukkan sumber modal perusahaan sangat tergantung dengan pihak luar. Selain itu besarnnya beban hutang yang ditanggung perusahaan dapat mengurangi jumlah laba yang diterima perusahaan. 
Himmatul Ulyah: Kebijakan Pendanaan dan Deviden

Perusahaan tumbuh signifikan lebih tinggi dibanding perusahaan yang tidak tumbuh, karena ada perusahaan yang memiliki kebijakan hanya membiayai ekspansinya dengan dana yang berasal dari sumber intern saja. Kebijakan tersebut dijalankan atas dasar pertimbangan bahwa kalau ekspansi dibiayai dengan laba yang berasal dari penjualan saham baru akan melemahkan kontrol dari kelompok dominan didalam perusahaan. Demikian pula apabila membiayai ekspansi dengan hutang akan memperbesar risiko financialnya. Mempercayakan pada pembelanjaan intern dalam rangka usaha mempertahankan kontrol terhadap perusahaan, berarti mengurangi pembagian dividennya.

Rasio dividend yields (DY), terdapat perbedaan yang signifikan dimana DY pada perusahaan tumbuh lebih rendah dibanding pada perusahaan tidak tumbuh. Hal ini dikarenakan pada perusahaan tumbuh akan memerlukan dana yang lebih besar dalam operasionalnya ke depan. Salah satu sumber pendanaan adalah dari arus kas perusahaan yang diperoleh dari laba ditahan perusahaan. Dengan besarnya kebutuhan dana yang harus digunakan oleh perusahaan yang tumbuh, maka bagian dividen yang dikeluarkan oleh perusahaan akan semakin rendah.

\section{PENUTUP}

Kesimpulan

Berdasarkan hasil penelitian dan pembahasan, maka kesimpulan penelitian yang penulis kemukakan adalah sebagai berikut:

Hasil penelitian menunjukkan terdapat perbedaan yang signifikan pada kebijakan pendanaan antara perusahaan manufaktur yang berpotensi tumbuh tinggi dan perusahaan yang berpotensi tumbuh rendah dengan menggunakan investment opportunity set. Nilai signifikan yang dihasilkan adalah sebesar 0,014 dimana nilai tersebut lebih rendah dari 0,05.

Hasil penelitian menunjukkan terdapat perbedaan yang signifikan pada kebijakan deviden antara perusahaan manufaktur yang berpotensi tumbuh tinggi dan perusahaan yang berpotensi tumbuh rendah dengan menggunakan investment opportunity set. Nilai signifikan yang dihasilkan adalah sebesar 0,006 dimana nilai tersebut lebih rendah dari 0,05.

\section{DAFTAR PUSTAKA}

Adi Prasetyo. 2000. Asosiasi antara Investment Opportunity Set (IOS) dengan kebijakan pendanaan, kebijakan Dividen, Kebijakan Kompensasi, Beta dan Perbedaan Reaksi Pasar : Bukti Empiris dari Bursa Efek Jakarta. 
Ihtiyath Vol. 2 No. 1 September 2018

Anonim. 2010. Indonesian Capital Market Directory 2010. Jakarta: ECFIN.

Brigham, Eugene F. dan Joel F. Houston. 1994. Dasar-Dasar Manajemen Keuangan. Edisi Kesembilan. Jilid 2. Jakarta: Erlangga.

Brigham, Eugene E., Louis C. Gapenski, dan Philip R. Daves. (1999). Intermediate Financial Management. 6th ed. Orlando: The Dryden Press.

Christian Herdinata. 2009. Kebijakan Pendanaan dan Dividen dengan Pendekatan Investment Opportunity Set, Jurnal Keuangan dan Perbankan Vol. 13. hal. 237-248.

Clarkson, P. Kao, J. L, and Richardson, G. D. 1994. The Voluntary inclusion of forecasts in the MD \& A section of Annual Report. Contemporary Accounting Research, Vol $11(1), 130$

Eduardus Tandelilin. 2001. Analisis Investasi dan Manajemen Portofolio. Edisi Pertama. Yogyakarta : BPFE

Gagarin Pagalung. (2002). Pengaruh Kombinasi Keunggulan dan Keterbatasan Perusahaan terhadap Set Kesempatan Investasi (IOS), Jurnal Riset Akuntansi Vol. 6. Hal. 249-263.

Gaver, J.J., dan Gaver, K.M. 1993. Additional Evidence on The Association Between The Investment Opportunity Set and Corporate Financing Dividend, and Compesation Policies, Journal of Accounting and Economic. pp. 125-160.

Husein Umar. 2003. Metode Riset Bisnis, Jakarta : PT Gramedia Pustaka Utama

Imam Ghozali. 2005. Aplikasi Analisis Multivariate dengan Program SPSS. Edisi 3, Semarang: Badan Penerbit Universitas Diponegoro.

Imam Subekti dan Indra Wijaya Kusuma. 2000. "Asosiasi antara Set Kesempatan Investasi dengan kebijakan Pendanaan dan Dividen Perusahaan, serta Implikasinya pada Perubahan Harga Saham." Simposium Nasional Akuntansi III. pp. 820-850

Isnaeni Rokhayati. 2005. Analisis Hubungan Investment Opportunity Set dengan Realisasi pertumbuhan serta Perbedaan Perusahaan yang Tumbuh dan Tidak Tumbuh terhadap Kebijakan Pendanaan dan Dividen di Bursa Efek Jakarta. SMART 1. hal. 41-60.

Jogiyanto Hartono. 2000. Teori portofolio dan Analisis Investasi, Yogyakarta: BPFE

Julianto Agung Saputro. 2003. Analisis Hubungan Antara Gabungan Proksi Investment 
Himmatul Ulyah: Kebijakan Pendanaan dan Deviden

Opportunity set dan Real Growth dengan menggunakan pendekatan Confirmatory Factor Analysis. Jurnal Riset Akuntansi Indonesia, Vol.6, No. 1, Hal : 69-92

Kallapur, S., dan Trombley, M.K. 2001. The Investment Opportunity Set: Determinants, Consequences, and Measurement, Managerial Finance 27. pp. 3-15.

Myers, Stewart C. 1977. Determinant of Corporate Borrowing, Journal of Financial Economics 5. pp. 147-175.

Nur Indriantoro dan Bambang Supomo. 2002. Metodelogi Penelitian Bisnis untuk Akuntansi dan Manajemen. BPFE: Yogyakarta

Sartono.R.Agus. 1998. Manajemen Keuangan. Edisi Ketiga, Yogyakarta: BPFE

Smith, Jr. W Clifford, dan Watts, R. L. 1992. The Investment Opportunity Set and Corporate Financing, Dividend and Compensation Policies, Journal of Financing Economics Vol. 32. pp. 263-292.

Suad Husnan. 2000. Manajemen Keuangan Teori dan Terapan (Keputusan Jangka Panjang). Buku I, Edisi keempat, Yogjakarta: BPFE.

Sudarsi, S. 2002. Analisis Faktor-faktor yang mempengaruhi Dividend Pay Out Ratio pada Industri Perbankan yang Listed di BEJ. Jurnal Bisnis dan Ekonomi. Vol. 9, No.1, hal.76-88

Sugiyono. 2012. Metode Penelitian Pendidikan (Pendekatan kuantitatif, kualitatif dan R\&D). Bandung : Alfabeta

Tettet Fijrijanti dan Jogiyanto Hartono M. 2000. Analisis Korelasi Pokok IOS Dengan Realisasi Pertumbuhan, Kebijakan Pendanaan dan Dividen. Simposium Nasional Akuntansi III Ikatan Akuntan Indonesia, Hal : 851-875

Uma Sekaran. 2009. Research Methods For Business: Metodologi Penelitian untuk Bisnis. Edisi Empat. Buku Satu. Jakarta: Salemba Empat.

Yetti Iswahyuni dan L. Suryanto. 2002. Analisis Perbedaan Perusahaan Tumbuh dan Tidak Tumbuh Dengan Kebijakan Pendanaan, Deviden, Perubahan Harga Saham Dan Volume Perdagangan Pada Bursa Efek Jakarta Dengan Pendekatan Asosiasi Proksi Invesment Opportunity Set (IOS).

Yuniningsih. 2003. Interdepensi antara kebijakan Dividen Pay out Ratio, Financial Leverage, dan Investasi pada Perusahaan Manufaktur yang Listed di BEJ. Jurnal Bisnis dan Ekonomi,Vol.9, No.2, September, hal. 164-182. 
Himmatul Ulyah: Kebijakan Pendanaan dan Deviden 
Himmatul Ulyah: Kebijakan Pendanaan dan Deviden 
Himmatul Ulyah: Kebijakan Pendanaan dan Deviden 
Himmatul Ulyah: Kebijakan Pendanaan dan Deviden 
Himmatul Ulyah: Kebijakan Pendanaan dan Deviden 
